\title{
Dignity and Human Rights in India
}

\author{
Sushant Chandra ${ }^{1}$ and Shireen Moti ${ }^{2}$
}

Jindal Global Law School

\begin{abstract}
.
This paper aims at exploring how the constitutional value of dignity has been used in adjudicating socio-economic rights under the Indian Constitution. The use of dignity in adjudicating socioeconomic rights has been done largely within the framework of liberty clause (Article 21) of the Indian Constitution with a few aberrations of situating the same under equality clause (Article 14). The paper nowhere claims that dignity is the only constitutional value that informs these adjudications of socio-economic rights. Its usage along with other constitutional values such as liberty, equality and freedom are highly interconnected. This paper evaluates all major judgments given by the Supreme Court and High Courts in understanding the meaning attributed to dignity; and how dignity has been used as a foundational principle in arguing for access to basic necessities - primarily education and healthcare in this paper. The first part of the paper articulates a theoretical framework on the lines of capability approach model proposed by Amartya Sen and later contributed to by Martha Nussbaum. The idea is to shed more light on

'why dignity should be used as a constitutional value in adjudicating socio-economic claims' and 'what all can it guarantee as far as basic necessities are concerned'. Largely, cases on education posit a fit within the theoretical framework premised on capability approach. The second part of the paper discusses the philosophical underpinnings of the use of 'dignity' as a constitutional value for the adjudication of socio-economic rights, including the right to healthcare and the right to education. The third part of the paper evaluates application of dignity in adjudicating healthcare claims. The Indian courts were initially locating healthcare claims under obligation oriented model with abysmal emphasis on rights under the liberty clause, and came across as conservative in opening the gateway of a right based approach to healthcare. However, with advent of time and assertion of judicial activism in other spheres of public life, courts became more assertive in responding to healthcare claims and employed dignity under liberty clause as well as under equality clause in adjudicating healthcare claims. The fourth part of the paper assesses education cases and maps the application of dignity in their adjudication. This part evaluates how Directive Principles
\end{abstract}

\footnotetext{
${ }^{1}$ Assistant Professor and Assistant Director, Clinical Program, Jindal Global Law School, O.P. Jindal Global University, Sonepat, Haryana, India.

${ }^{2}$ Senior Research Associate and faculty coordinator, Clinical Program, Jindal Global Law School, O.P Jindal Global University, Sonepat, Haryana, India.
} 
of State Policies have imparted life to right based discourse to education within the capability framework. The final part of the paper is the conclusion.

Keywords: liberty, equality, fundamental rights, social-minimum, social justice, substantive equality, healthcare, education, Kant, Sen, Nussbaum, Supreme Court of India, Allahabad High Court, Delhi High Court

\section{Historical background:}

The term dignity has been historically associated with 'ranks' 'status' and 'reputation' of individuals and hence enjoined a certain behavior. The term has been associated with institutions, nations and people. Chris writes that it's only in classical Roman literature there are incidental references of dignity wherein dignitas referred to 'the dignity of human beings as human beings, not dependent on any particular additional status.' In locating the value of dignity, Cicero compares man with animals:

It is vitally necessary for us to remember always how vastly superior is man's nature to that of cattle and other animals; their only thought is for bodily satisfactions....Man's mind on the contrary, is developed by study and reflection....From this we may learn that sensual pleasure is wholly unworthy of the dignity of the human race. ${ }^{3}$

The frequent usage of dignity across different disciplines led philosophers and lawyers use the term in ushering in socio-economic claims. Friedrich Schiller's epigram, Wurde des Menschen (1978) attempts to portray this connection, and he writes: 'give him food and shelter;/When you have covered his nakedness, dignity will follow by itself. ${ }^{45}$ The term, since its inception, had a ubiquitous appeal. What differed was the way in which it has been understood in different nations and cultures. In Europe and Latin America, dignity has been conceived as a societal cry opposing slavery. The term has also been associated with labor movements and has been touted as a basis for claiming social welfare scheme from the state. ${ }^{5}$ Dignity, Political Philosophy and Indian Constitution:

Human dignity has its root in the Kantian ethical philosophy. Kantian categorical imperative requires that human beings should never be treated 'simply as a means, but always at the same time as an end. ${ }^{6}$ Kant uses the term Wurde that fairly translates to dignity, and refers to the term 16 times in Groundwork to the Metaphysics of Morals. ${ }^{7}$ Kant uses dignity to mean 'unconditional, incomparable value'. ${ }^{8}$ It is in this sense, human dignity is 'non-derogable' - a phrase that the Indian

\footnotetext{
${ }^{3}$ Cicero, De Officiis, I, at 30

${ }^{4}$ Cancik, "Dignity of Man" and "Personal" in Stoic Anthropology: Some Remarks on Cicero, De Officiis I, at page

${ }^{5} 5$ Alan Flanders has argued, e.g., that the value of a trade union to its members is 'less in its economic achievement than in its capacity to protect their dignity': A. Flanders, Management and Unions (1970), at 239

${ }^{6}$ ImManuel Kant, The Moral LaW: Kant's Groundwork Of The Metaphysics Of MoRals 96 (H J Patron tr., Routledge 1963), discussed in D MEYERSON, RIGHTS LIMITED, 12-13(1997).

${ }^{7}$ Id; See Michael Rosen, Dignity - IT’s History AND MEANing, 20-21 (Harvard University Press, 2012,).

${ }^{8}$ Id.
} 
Courts have started applying in adjudicating socio-economic claims. ${ }^{9}$ Kant grounded dignity in autonomy and stated, 'autonomy is therefore the ground of dignity of human nature' ${ }^{10}$ It is this

idea of autonomy that attributes 'human beings as agents capable of making moral choices'. ${ }^{11}$ Martha Nussbaum expresses it by stating that:

The core idea is that of the human being as a dignified free being who shapes his or her own life in cooperation and reciprocity with others, rather than being passively shaped or pushed around by the world in the manner of a 'flock' or 'herd' animal. A life that is really human is one that is shaped throughout by these human powers of practical reason and sociability. ${ }^{12}$

The capability approach as devised by Sen and developed by Nussbaum provides for holding state accountable for providing access to fundamental basic necessities. ${ }^{13}$ The theoretical framework derives its flesh and blood from human dignity grounded in autonomy - ascribing sacredness to moral choices each individual has in creating life of her choice. ${ }^{14}$ These capabilities have special status in enabling the individuals in pursuing the choices they could make. The claim to different sets of capabilities depends on the factors that imbue the society where a claim is sought. It's contested whether a common list of capabilities could be made due to difficulty 'in seeing how the exact lists and weights would be chosen without appropriate specification of the context of their use (which could vary)'. ${ }^{15}$ The concept of 'social minimum, 1617 or 'intellectual capability' 18 that Indian courts have devised in responding to socio-

12 MARTHA, Id at 72 .

13 MARTHA, supra note 6.

14 MARTHA, supra note 6.

15 See K Van Marle, The Capabilities Approach, The Imaginary Domain and Asymmetrical Reciprocity - Feminist Perspective On Equality And Justice, 11 Feminist Legal Studies, 255-78 \& 272-273 (2003).

16 Consumer Education Research Society v. Union of India, para 18, (1995) 3 SCC 42 (India): [I]n other words, the aim of social justice is to attain substantial degree of social, economic and political equality, which

is the legitimate expectation. Social security, just and humane conditions of work and leisure to workman are part of his meaningful right to life and to achieve self-expression of his personality and to enjoy the life with dignity; the state should provide facilities and opportunities to enable them to reach at least minimum standard of health, economic security and civilized living while sharing according to their capacity, social and cultural change.

17 Francis Carolie v. Administrator of Delhi, AIR 1981 SC 746 (India), (initially the scheme of the state was to simply safeguard life but that got changed to 'dignified life' and in that changed the obligations of the state too to maintain dignified life of individuals. One of the ways of doing it is developing 'condition precedent' to securing a dignified life. The 'condition precedent' to dignified life also referred to as 'social minimum' has its foundations in 'bare minimum expression of human self' (Francis Carolie) and autonomy of individuals. In Carolie, though obiter, the

\footnotetext{
${ }^{9}$ Md. Ahmed (minor) v. Union of India, (2014) 6 HCC (del) 118 (India).

${ }^{10}$ Michael Rosen, Dignity - IT’s History And MEANing, 21 (Harvard University Press, 2018) .

${ }^{11}$ Martha Nussbaum, Women And Human DeVelopment - The CAPABILITIES Approach (Cambridge, 2000).
} 
court rules: but the question which arises is whether the right to life is limited only to protection of limb or faculty or does it go further and embrace something more. We think that the right to life includes the right to live with human dignity and all that goes along with it, namely the bare necessaries of life such as adequate nutrition, clothing and shelter and facilities for reading, writing and expression oneself in diverse forms, freely moving about and mixing and commingling with fellow human beings. Of course, the magnitude and content of the components of this right would depend upon the extent of the economic development of the country, but it must, in any view of the matter, include the right to the basic necessities of life and also the right to carry on such functions and activities as constitute the bare minimum expression of self.)

18 Ramji Tiwari v. State of U.P., (1997)1UPLBEC690 (India): The Allahabad High Court granted equal pay to teachers teaching in unaided primary school. It grounded its reasoning in teachers playing a pivotal role in developing 'intellectual capability' in students. It also referred to the supreme court's judgments in Andhra Kesari Education Society v. Director of School Education (1988) 4 SC 431(India) \& State of Maharashtra v. Vikas Sahebrao Roundale (1992) 5 SC 175(India) wherein it observed: though teaching is the last choice in the job market, the role of teacher is central to all processes of formal education. The teacher alone could bring out the skills and intellectual capabilities of students. He is the engine of the educational system. He is a principal instrument in awakening the child to cultural values. He needs to be endowed and energized with needed potential

economic claims pertaining to healthcare and education are consistent with theoretical framework espoused by capability approach. ${ }^{19}$ In explicating the content of 'social minimum' the Supreme Court has held that 'such facilities and opportunities' 12 that enable individual to reach 'minimum standards of health and civilized living ${ }^{13}$ constitutes social minimum. Further, in expanding on 'social minimum' Indian courts have also reflectively engaged with Directive Principles of State Policies (hereinafter the "DPSPs") ${ }^{14}$ and General Comment No. 3 issued by United Nations Committee on Economic, Social and Cultural Rights. ${ }^{15}$ The courts have not simply borrowed the principles from these instruments but engaged reflectively and applied reason ${ }^{24}$ that Sen employs in resolving quandary regarding access to capabilities. The Courts have held that the basis of harmonious interpretation principle between Part III and Part IV is dignity inherent in an individual. ${ }^{16}$ The courts while laying down social minimum have not only engaged reflectively with DPSPs in Part IV and General Comment but has been mindful of its institutional limitations

\footnotetext{
${ }^{12}$ Consumer Education Research Society v. Union of India, para 18, (1995) 3 SCC 42 (India).

${ }^{13} I d$.
}

${ }^{14}$ [T] his right to live with human dignity enshrined in article 21 derives its life breath from the directive principles of state policy and particularly clauses (e) and (f) of article 39 and articles 41 and 42 and at the least, therefore, it must include protection of the health and strength of workers men and women, and of the tender age of children against abuse, opportunities and facilities for children to develop in a healthy manner and in conditions of freedom and dignity, educational facilities, just and humane conditions of work and maternity relief. These are the minimum requirements which must exist in order to enable a person to live with human dignity and no state - neither the central government nor any state government - has the right to take any action which will deprive a person of the enjoyment of these basic essential.

Bandhua Mukti Morcha v. Union of India, AIR 1984 SC 802 (India).

${ }^{15}$ Md. Ahmed (minor) v. UOI, para 43, (the committee, in general comment no. 3, confirmed that states parties have a core obligation to ensure the satisfaction of, at the very least, minimum essential levels of each of the rights enunciated in the covenant, including essential primary healthcare.) ${ }^{24}$ Marle, supra note 10.

${ }^{16}$ Unnikrishnan v. State of A.P., (1993) 1 SCC 645 (India). ([B]oth part III and IV...have to be balanced and harmonized then alone the dignity of the individual can be achieved. They (fundamental rights and directive principles) were meant to supplement each other.” (quoting Shelat, J., and Grover J., in Kesavananda Bharati v. State of Kerala AIR 1973 SC 1461(India))). 
in deciding policy issues ${ }^{17}$, urgency of the claim and impact of denial. ${ }^{18}$ In developing 'social minimum' courts have also been mindful of issues of inadequate budgetary allocation towards important socio-economic rights ${ }^{19}$, improper utilization of already allocated budget ${ }^{29}$ and inadequate policy measures affecting important capabilities and thereby

to deliver enlightened service expected of him. His quality should be such as would inspire and motivate into action the benefiter. He must keep himself abreast of ever changing conditions. He is not to perform in a wooden and in imaginative way.

19 Nussbaum's approach is compatible with a range of different theories about the degree of material equality that should be guaranteed in a just society from complete egalitarianism, a rawlsian difference principle, and a focus on an ample social minimum for all. see Sandra Liebenberg, The Value Of Human Dignity In Interpreting SocioEconomic Rights, 21 South African Journal Of Human Rights, 10 (2005).

impacting choices made by people. ${ }^{20}$ In adjudicating social rights cases, there is a growing trend, in locating important interests within autonomy rights that demand constitutionalisation of socioeconomic rights - which were earlier considered to be non-justiciable. ${ }^{21}$ In engaging with issues related to judicial legitimacy and institutional competence in devising 'social minimum' the courts have employed dignity in demanding explanations regarding the use of allocated budget on a given entitlement. ${ }^{22}$ In Snehlata $v$. State of U.P. ${ }^{23}$ the court directed the state to provide explanation regarding its inability to spend the allocated budget on the healthcare when individual healthcare interest infractions were rampant in the state. ${ }^{24}$ The South African Constitutional Court applies this method of engagement in providing for systemic social rights. ${ }^{25}$ This remedy is particularly hailed, as it respects the principles of separation of power and institutional limitations of judiciary in designing social policies. ${ }^{26}$ It's interesting how dignity, grounded in autonomy, when used as a constitutional value could demand and obtain different outcomes in view of institutional competence.

Dignity, Right to Health and Healthcare, Indian Courts the Indian Constitution:

\footnotetext{
${ }^{17}$ State of Punjab v. Ram Lubhaya Bagga (1998) 4 SCC 118

${ }^{18}$ Parma and Kitara v. Union of India, (1989) 4 SCC 286(India); Mohr. Ahmed (minor) v. Union of India, (2014) 6 HCC (DEL) 118(India).

${ }^{19}$ Md. Ahmed (minor) v. Union of India, para 52, (2014) 6 HCC (DEL) 118 (India).

29 Sinhala v. State of U.P., PIL NO. 14588 of 2009 (Allahabad High Court) (India).

${ }^{20}$ Mohr. Ahmed (minor) v. Union of India, para 52, (2014) 6 HCC (DEL) 118 (India).

${ }^{21}$ CECILE FABRe, Social Rights Under The CONSTITUTION 101 (2000) (she argues that such rights protect the vital interest individuals have in autonomy and well-being.)

${ }^{22}$ Sinhala v. State of U.P., PIL No. 14588 of 2009 (Allahabad High Court) (India).

${ }^{23} I d$.

${ }^{24} I d$.

${ }^{25}$ Madhab Khosla, Making Social Rights Conditional - Lessons From India, International Journal Of Constitutional Law (2010), https://academic.oup.com/icon/article/8/4/739/667097.

${ }^{26}$ MARK TOTIENT, WEAK COURTS, STRONG RIGHTS: JUDICIAL REVIEW AND SOCIAL WELFARE RIGHTS IN COMPARATIVE CONSTITUTIONAL LAW (Princeton University Press, 2008).
} 
The centrality of health as an important aspect of the human condition is universally recognized. ${ }^{27}$ As the World Health Organization (hereinafter the "WHO") has written: "[W]ithout health other rights have little meaning". ${ }^{28}$ The widely accepted definition of health is given by the WHO in the preamble of its Constitution. According to the WHO, "health is a state of complete physical, mental and social wellbeing and not merely an absence of disease". ${ }^{29} \mathrm{WHO}$ has played a supportive role in guiding health policy development and action at the global and national levels, with an overall objective of ensuring and attaining the highest standards of healthcare to all the people around the world. ${ }^{30}$ WHO has not only given a wider definition to health but also developed the vision of healthcare. ${ }^{41}$

The right to health entails at least three distinct, though interrelated, entitlements for individuals and groups: the right to adequate protection of health, the right to equal access to healthcare and, more generally, the right to the creation of conditions favorable to the achievement of maintenance of the highest attainable level of health. ${ }^{3132}$ The right to health may be seen as having two components: a right to healthcare and a right to healthy conditions. ${ }^{43}$ The rights-based approach to health incorporates both a clinical, curative perspective focusing on healthcare and health services, and a public health, preventive perspective focusing on the social determinants of health-including water, sanitation, nutrition, and health education. ${ }^{33}$

Under international law, there is a right not merely to healthcare but to the much broader concept of health. ${ }^{34}$ Because rights must be realized inherently within the social sphere, this formulation immediately suggests that determinants of health and ill health are not purely biological or "natural" but are also factors of societal relations. Thus, a rights perspective is entirely compatible with work in epidemiology that has established social determinants as fundamental causes of disease. $^{35}$

\footnotetext{
${ }^{27}$ Steven D. Jamar, the International Human Right to Health, 22 S.U. L. Rev. 1 (1994) 2.

${ }^{28} I d$.

${ }^{29}$ WORLD Health ORganization, W.H.O. CONSTITUTION, in Basic DOCUMENTS OF THE WORLD HEALTH ORGANIZATION (37th ed. 1992); see also UN Doc. A/CONF. 32/8. Of particular significance in this definition is the term "social well-being" which WHO proposed for inclusion in the Covenant on Social, Economic and Cultural Rights, but which was deleted in the drafting and revision process as being too expansive. If social well-being is a part of health as a human right, then the right to health could swallow the entire field of human endeavor and thus effectively lose any legal meaning.

${ }^{30}$ Md. Baharul Islam, Right to Health: A Constitutional Mandate in India, 3 IJARIIE (2017) 2628. ${ }^{41}$ Id.

${ }^{31}$ Aart Hendriks, the Right to Health in National and International Jurisprudence, 5 Eur. J. Health L. (1998) 394. ${ }^{43}$

W. Courtland Robinson, the Right to Health and Basic Services. Studies in Transnational Legal Policy, (2016)

${ }^{32}$, https://www.brookings.edu/wp-content/uploads/2016/06/0119_internal_displacement_Ch6.pdf.

${ }^{33} \mathrm{Id}$.

${ }^{34}$ Alicia Ely Yamin, the Right to Health Under International Law and its relevance to United States, Am J Public Health (2005) 1156, https://www.ncbi.nlm.nih.gov/pmc/articles/PMC1449334/

${ }^{35} I d$.
} 
The global community treats health as the part of International human rights law. ${ }^{36}$ The right to the highest attainable standard of health is a human right recognized in international human rights law. ${ }^{37}$ It is recognized in numerous international and regional instruments, starting with the Universal Declaration of Human Rights (Article 25) and including the International Covenant of Social Economic Rights (Article 12), the Convention on the Rights of the Child (Article 6, 24), and the Convention on the Elimination of All Forms of Discrimination against Women (Article 10, 11, 12, 14). ${ }^{38}$

According to the General Comment 14 of the Committee for Economic, Social and Cultural Rights, "the right to health requires availability, accessibility, acceptability, and quality with regard to both healthcare and underlying preconditions of health." The Committee interprets the right to health, as defined in Article 12.1, as an inclusive right extending not only to timely and appropriate healthcare but also to the underlying determinants of health, such as access to safe and potable water and adequate sanitation, an adequate supply of safe food, nutrition and housing, healthy occupational and environmental conditions, and access to health-related education and information, including on sexual and reproductive health. ${ }^{39}$

India's commitment to providing healthcare to its citizens stems not only from its constitutional mandate and progressive interpretation of the duty of the State, ascribed to it by various judicial pronouncements but also from its international commitments. ${ }^{40}$ The state has the duty to provide health to the people. ${ }^{41}$ The Indian constitution does not guarantee a right to health as a fundamental right. ${ }^{42}$ Part IV of the Indian Constitution which is the directive principle of state policy (hereinafter the "DPSPs") imposes duty on states. It directs the state to take measures to improve the condition of healthcare of the people. ${ }^{43}$

Articles 38 impose liability on state that state secure a social order for the promotion of welfare of the people but without public health we can't achieve it. ${ }^{44}$ Article 39(e) related with workers to protect their health. ${ }^{45}$ Article 41 imposed duty on state to public assistance basically for those who are sick \& disable. ${ }^{46}$ Article 42 it's a primary responsibility of the state to protect the health of

\footnotetext{
${ }^{36}$ S. P. Srivastava, Public Health and Right to Health in India: Evaluation of Gap between Policy and Implementation, 2 Nirma U. L.J. (2012) 7.

${ }^{37} \mathrm{WHO}$, Office of the high commissioner of human rights, right to health, factsheet no. 31,13 , https://www.ohchr.org/Documents/Publications/Factsheet31.pdf

${ }^{38} I d$ at $9-11$.

${ }^{39}$ Office of the High Commissioner of Human Rights, General comment 14, CESCR General Comment No. 14: The Right to the Highest Attainable Standard of Health (Art. 12), 4, https://www.refworld.org/pdfid/4538838d0.pdf

${ }^{40}$ Karthy Nair \& Pallavi Sharma, Delivering the Right to Health to the Rural Sector, 4 NUJS L. Rev. 391 (2011) 393.

${ }^{41} I d$.

${ }^{42}$ Mahesh Sharma Poudel, Right to Health and Its Jurisprudence: An Overview, 5 NJA L.J. (2011) 237.

${ }^{43} \mathrm{Id}$.

${ }^{44}$ The Constitution of India 1950, art. 38.

45 The Constitution of India 1950, art. 39 (e).

${ }^{46}$ The Constitution of India 1950, art. 41. ${ }^{58}$

The Constitution of India 1950, art. 42.
} 
infant $\&$ mother by maternity benefit. ${ }^{58}$ Article 47 of the states that the improvement of public health should be regarded as one of the state's fundamental duties. ${ }^{47}$

The DPSPs are not enforceable in court. ${ }^{60}$ However, the Constitution declares that the Principles are fundamental to the governance of the country. ${ }^{48}$ Therefore, each branch of government must act to further the Principles, and use them to implement state policy as part of the state's commitment to the welfare of the Indian people. ${ }^{49}$ In fact, it is considered the constitutional duty of the Executive, Legislative, and Judicial branches to apply the Principles when making law for the country. ${ }^{50}$

'Dignity' has been used as a constitutional value to adjudicate right to healthcare in India largely under the framework of liberty clause (Article 21) of the Indian Constitution. In numerous cases, dealing with the substantive content of the right to life, the Court has found that the right to live with human dignity includes the right to good health. ${ }^{51}$ In Francis Coralie Mullin v. Administrator, Union Territory of Delhi, ${ }^{52}$ this Court acknowledged that the right to life guaranteed by Article 21 of the Constitution includes the right to live with dignity which includes, inter alia, nutrition, clothing and shelter-all of which require some finances.

In Bandhua Mukti Morcha v. Union of India, ${ }^{53}$ the Supreme Court observed that protection of health and opportunities for healthy development are among the minimum requirements which must exist in order to enable a person to live with human dignity. The 'right to life' is interpreted to mean the right to good health, and unpolluted air and water. In Virender Gour v. State of Haryana, ${ }^{54}$ the Supreme Court observed that environmental ecological, air, water, pollution, etc. should be regarded as amounting to violation of Article 21. Therefore, hygienic environment is an integral facet of right to healthy life and it would be impossible to live with human dignity without a humane and healthy environment.

In State of Punjab v. Mohinder Singh Chawla ${ }^{55}$, Nagar Nigam v. AL Faheem Meat Exports $(P)$ Ltd. ${ }^{56}$ and in Occupational Health and Safety Association v. Union of India, ${ }^{57}$ the right to health was given the status of a fundamental right flowing from Article 21 of the Constitution. In

\footnotetext{
47 The Constitution of India 1950, art. 47; Sheetal B. Shah, Illuminating the Possible in the Developing World: Guaranteeing the Human Right to Health in India, 32 Vand. J. Transnat'l L. (1999) 465; Supra note 51 at 396.60 Sheetal B. Shah, Illuminating the Possible in the Developing World: Guaranteeing the Human Right to Health in India, 32 Vand. J. Transnat'l L. (1999) 465.

${ }^{48}$ Id.

${ }^{49}$ Supra note 60.

${ }^{50}$ Supra note 60.

${ }^{51}$ Supra note 60 at 476.

${ }^{52}$ Francis Coralie Mullin v. Administrator, Union Territory of Delhi, (1981) 1 SCC 608.

${ }^{53}$ Bandhua Mukti Morcha, A.I.R. 1984 S.C.

${ }^{54}$ Virender Gour v. State of Haryana, 1994 SUPPL. (6) SCR 78.

55 State of Punjab v. Mohinder Singh Chawla, (1997) 2 SCC 83 at 4.

${ }^{56}$ Nagar Nigam v. AL Faheem Meat Exports (P) Ltd, (2006) 13 SCC 382 at 26.

${ }^{57}$ Occupational Health and Safety Association v. Union of India, (2014) 3 SCC 547 at 10.
} 
Consumer Education Research Society v. Union of India, ${ }^{58}$ and in Kirloskar Brothers Ltd. $v$. Employees' State Insurance Corporation, ${ }^{59}$ the Supreme Court held that the right to health and healthcare of a worker is a component of the fundamental right to life guaranteed under Article 21 read with Article 39(e), 41 and 43 of the Constitution of India. It is pertinent to note that in these cases the Court has engaged effectively and applied reason while dealing with DPSPs and General Comment no. 3 of United Nations Committee on Economic Social and Cultural Rights.

In Ashwani Kumar v. Union of India (UOI) and Ors, ${ }^{60}$ the Supreme Court observed that right to life provided for in Article 21 of the Indian Constitution must be given an expansive meaning. The right to life, encompasses several rights, including three important constitutional rights, each one of them being basic and fundamental. These rights are the right to live with dignity, the right to shelter and the right to health. The State is obligated to ensure that these fundamental rights are not only protected but are enforced and made available to all citizens.

However, there have been a few deviations, wherein 'dignity' has informed the adjudication of the right to healthcare under the equality clause (Article 14) of the Indian Constitution. In Kirloskar Brothers Ltd. v. Employees' State Insurance Corporation, ${ }^{61}$ the Supreme Court observed that in expanding economic, activities in liberalised economy Part IV of the Constitution enjoins not only the State and its instrumentalities but even private industries to ensure safety to the workmen and to provide facilities and opportunities for health and vigour of the workman assured in relevant provisions in part IV which are integral part of right to equality under Article 14 and right to invigorated life under Article 21 which are fundamental rights to the workman. It is interesting to note that the concept of 'social minimum' or 'intellectual capability' have been devised by Indian courts to respond to socio-economic claims pertaining to healthcare. In Consumer Education Research Society v. Union of India, ${ }^{62}$ the Court observed that the state should provide facilities and opportunities to enable people to reach at least minimum standard of health, economic security and civilized living while sharing according to their capacity, social and cultural change. Francis Carolie v. Administrator of Delhi, ${ }^{63}$ the Court observed that one of the ways that the state can ensure a dignified life is to develop 'condition precedent' to securing a dignified life. The condition precedent to a dignified life also referred to as 'social minimum' has its foundations in 'bar minimum expression of human self and autonomy of individuals.

The Courts while laying down social minimum have been mindful of its institutional limitations in deciding policy issues. For example, in Snehalatav. State of Uttar Pradesh, ${ }^{64}$ the Court directed the state to provide explanation regarding its inability to spend the allocated budget on the healthcare when individual healthcare interest infractions were rampant in the state. Thus, the Court acknowledged the fact that there is improper utilization of already allocated budget. In

\footnotetext{
${ }^{58}$ Consumer Education Research Society v. Union of India, (1995) 3 SCC 42 (India).

${ }^{59}$ Kirloskar Brothers Ltd. v. Employees' State Insurance Corporation, (1996) 2SCC 682 (India).

${ }^{60}$ Ashwani Kumar v. Union of India (UOI) and Ors, (2019)1 SCC (LS) 465.

${ }^{61}$ Kirloskar Brothers Ltd. v. Employees' State Insurance Corporation, (1996) 2SCC 682 (India).

${ }^{62}$ Consumer Education Research Society v. Union of India, (1995) 3 SCC 42 (India).

${ }^{63}$ Francis Carolie v. Administrator of Delhi, AIR 1981 SC 746 (India).

${ }^{64}$ Snehlata v. State of U.P., PIL NO. 14588 of 2009 (Allahabad High Court) (India).
} 
Paschim Bangal Khet Mazdoor Society v. State of West Bengal, ${ }^{65}$ while detailing the facilities that should be made available at primary and district health levels. It was observed that, it is no doubt true that financial resources are needed for providing these facilities. But at the same time it cannot be ignored that it is the Constitutional obligation of the State to provide adequate medical services to the people. Whatever is necessary for this purpose has to be done.

$\underline{\text { Right to education, Dignity, Indian Courts and the Indian Constitution: }}$

Education is intrinsically valuable as humankind's most effective tool for personal empowerment. ${ }^{66}$ Education takes on the status of a human right because it is integral to and enhances human dignity through its fruits of knowledge, wisdom and understanding. ${ }^{67}$ Moreover, for instrumental reasons education has the status of a multi-faceted social, economic and cultural human right. ${ }^{68}$ It is a social right because in the context of the community it promotes the full development of the human personality. ${ }^{69}$ It is an economic right because it facilitates economic self-sufficiency through employment or self-employment. ${ }^{70}$ It is a cultural right because the international community has directed education towards the building of a universal culture of human rights. ${ }^{71}$ In short, education is the very prerequisite for the individual to function fully as a human being in modern society. ${ }^{85}$

After the Second World War, the right to education became a part of international human rights law. ${ }^{72}$ It was included in the UDHR, the First Optional Protocol to the European Convention on Human Rights and Fundamental Freedoms (hereinafter the "ECHR"), the ICESCR and in a number of other international instruments. ${ }^{87}$ The focal point and ultimate basis of the right to education is the unequivocal commitment to the dignity inherent in every human being and hence to the development of the human personality. ${ }^{73}$ The UDHR and the ICESCR expressly emphasize this point in the very articles dealing with the right to education. ${ }^{89}$ Other instruments like ECHR make only indirect reference to human dignity as the anchor point for the right to education, i. e. by reference to the UDHR which the Council of Europe intended to implement by the adoption of the European Convention. ${ }^{74}$

The Constitution of India, promulgated soon after the independence in 1947 accepted the crucial role of education in the development of the nation and provided a legal basis for education. Based

\footnotetext{
65 Paschnn Banga Khet Alazdoor Sainity v. State of We4s t Bengal, (1996) 4 SCC 37.

${ }^{66}$ Richard Pierre Claude, The Right to Education and Human Rights Education, 2 SUR - Int'1 J. on Hum Rts. (2005).37.

${ }^{67}$ Id.

${ }^{68}$ Supra note 78.

${ }^{69}$ Supra note 78.

${ }^{70}$ Supra note 78.

${ }^{71}$ Supra note 78.

${ }^{85}$ Supra note 78.

${ }^{72}$ Fons Coomans, Justiciability of the Right to Education, 2 Erasmus L. Rev. (2009) 427. ${ }^{87}$ Id.

${ }^{73}$ Jost Delbruck, The Right to Education as an International Human Right, 35 German Y.B. Int'l L. (1992) $98{ }^{89}$ Jost Delbruck, The Right to Education as an International Human Right, 35 German Y.B. Int'1 L. (1992) 98. ${ }^{74}$ Id.
} 
on the principles of 'Justice', 'Liberty', 'Equality' and 'Fraternity', the Constitution is designed at furthering the goal of social revolution. The core of commitment to this social revolution lies in Parts III and IV, i.e. the Fundamental Rights, and DPSPs which may be termed as the conscience of the Constitution..$^{75}$ India being a signatory of the UDHR reflects various concerns of UDHR through various articles of its Constitution. For instance, Article 26 of the

UDHR which

reads

"Everyone has a right to education. ${ }^{76}$ Education shall be free at least in the elementary and fundamental stages..", finds an expression in the Indian Constitution under Article 41 and Article $45 .{ }^{77}$ Article 41 directs that, "the state shall within the limits of its economic capacity and development make effective provision for securing the rights to work, to education and to public assistance in case of unemployment, old age, sickness and disablement and in other cases of unreserved want". The Constitution recognizes education as one of the pious obligations of the state. Article 45 directs the state to endeavour to provide within a period often years from the commencement of the Constitution free and compulsory education for all children up to the age of 14 years. $^{78}$

In the year 2010, the country achieved a historic milestone when Article 21-A and the Right of Children to Free and Compulsory Education (RTE) Act, 2009 became operative on 1st April $2010 .{ }^{79}$ The enactment of the Constitution (Eighty-sixth Amendment) Act, 2002 led to the insertion of Article 21A, a justiciable fundamental right, in these terms: "The State shall provide free and compulsory education to all children of the age of six to fourteen years in such manner as the State may, by law, determine." At the same time, the constitutional amendment also altered Article 45 of the Constitution states that "the State shall endeavour to provide early childhood care and education for all children until they complete the age of six years." ${ }^{80}$ The Right to Free and Compulsory Education Act, 2009, makes education a fundamental right. ${ }^{81}$

The Courts have made use of 'dignity' to adjudicate the right to education within the framework of the liberty clause (Article 21) of the Constitution read along with DPSPs. Whether the right to education was a fundamental right and enforceable was answered in the affirmative by the Supreme Court in Mohini Jain v State of Karnataka. ${ }^{82}$ This was reiterated in Unni Kuishnan $v$ State of Andhra Pradesh. ${ }^{83}$ In Maharashta State Board of Secondary and Higher Education $v$ KS. Gandhi ${ }^{84}$ right to education at the secondary stage was held to be a fundamental right. In Unni

\footnotetext{
${ }^{75}$ Saroj Pandey, Education as a Fundamental Right in India: Promises and Challenges, 1 Int'l J. Educ. L. \& Pol'y (2005)13.

${ }^{76} I d$.

${ }^{77}$ Supra note 91.

${ }^{78}$ Supra note 91 at 14.

${ }^{79}$ Alka Muddgal and Charu Sethi, A Study of the Challenges of Right to Education Act 2009 Among Municipal Corporation Primary School Teachers of Delhi, 3(1) AIJTE (2017) 1.

${ }^{80}$ Rishad Chowdhury, The Road Less Travelled: Article 21A and the Fundamental Right to Primary Education in India, 4 Indian J. Const. L. (2010) 24.

${ }^{81}$ Supra note 95.

${ }^{82}$ Mohini Jain v State of Karnataka, AIR 1992 SC 1858.

${ }^{83}$ Unni Kuishnan v State of Andhra Pradesh, AIR 1993 SC 2178

${ }^{84}$ Maharashta State Board of Secondary and Higher Education v KS. Gandhi, 1991 SCALE (1)187.
} 
Kuishnan $v$ State of Andhra Pradesh, ${ }^{85}$ a constitution Bench had held education up to the age of 14 years to be a fundamental right. It would be therefore incumbent upon the State to provide facilities and opportunity as enjoined under Article 39(e) and (f) of the Constitution and to prevent exploitation of their childhood due to indigence and vagary.

\section{Conclusion:}

The South African Constitution's socio-economic rights provisions have been celebrated internationally. The socioeconomic rights protected by the South African Constitution include rights to housing, healthcare, food, water, social security, and education, among others. The South African Constitutional Court, in several of its cases has interpreted the the socio-economic rights provided enunciated in the South African Constitution. It is pertinent to note that the South African cases illustrate that courts, acting cautiously, can enforce such rights without destroying separation of powers or taxing judicial competency ${ }^{86}$ Moreover, the model followed by the South African

Constitutional Court is commended as it respects the principles of separation of power and institutional limitations of judiciary in designing social policies. ${ }^{103}$

${ }^{85}$ Unni Kuishnan v State of Andhra Pradesh, AIR 1993 SC 2178.

${ }^{86}$ Mark S. Kende, The South African Constitutional Court's Embrace of Socio Economic Rights: A Comparative Perspective, 6 CHAP. L. REv. (2003) 142. ${ }^{103}$ Supra note 34. 